\title{
Optimization of the Support Structure of Large Axial-Radial Bearing of Overhead Type Manipulator \\ Faculty of Mechanical Engineering
}

Slovenia

Jurij Hladnik

Teaching Assistant University of Ljubljana Faculty of Mechanical Engineering
Slovenia

\section{Franc Resman}

Technical Assistant University of Ljubljana Faculty of Mechanical Engineering
Slovenia

\section{Christian Landschützer}

Assoc. Professor Graz University of Technology Institute for Technical Logistics Austria
Large axial-radial bearings are widely used as means of attachment of slewing mechanisms of cranes and heavy machinery. In case of an inadequate support structure these loadings can hinder proper functioning of the slewing bearing or even lead to its terminal failure. In the paper support of a large-radial bearing mounted on an overhead type manipulator was optimized with the goal of minimization of the peaks of the reaction forces acting between the bearing ring and the bearing support and of increase of the uniformity of the reaction forces. A finite element model of the overhead travelling manipulator was established and the support structure reinforcement configuration was successively optimized. In the final solution maximum tensile and compressive reaction forces were reduced by $13 \%$ in comparison to the initial solution. Also the uniformity of tensile and compressive maximal reaction forces was improved by $74 \%$ and $70 \%$, respectively.

Keywords: Large-diameter bearings, force peak minimization, finite element method, support structure optimization.

\section{INTRODUCTION}

Large axial-radial slewing bearings are incorporated into various heavy equipment and material handling machinery, such as excavators and cranes. Their purpose is to enable the rotary movement between the supporting structure (e.g. undercarriage frame) and the slewing superstructure. The slewing superstructure is most often a hydraulic mechanism that produces axial, radial and tilting moment loadings onto the bearing and on the supporting structure [1]. For compensation of the tilting moment, which is the most problematic loading, [2] bearings with large diameter are desired. Due to the construction space limitation the bearing diameters are limited in size. Consequently, large forces appear at the bearing's circumference in the axial direction. These forces are transmitted to the bearing support causing deformations and stresses. In case of an inadequate bearing support these deformations can hinder rotation of the slewing structures or lead to bearing failure or even material structural failure.

Lazovic et al. [3] investigated the unequal load distribution between the rolling elements of bearings via a mathematical model. They claimed that the degree of load distribution inequality depends on a number of factors: character and magnitude of external load, contact stiffness of the bearing parts, accuracy of their sizes and form, as well as internal radial clearance.

Many researchers have found stiffness of the supporting structure as a crucial constructional problem of large slewing mechanisms [1, 4-8]. They concluded that the supporting structure needs to assure stiff and

Received: January 2018, Accepted: March 2018

Correspondence to: Dr Boris Jerman

Faculty of Mechanical Engineering,

Aškerčeva 6, 1000, Ljubljana, Slovenia

E-mail: boris.jerman@fs.uni-lj.si

doi:10.5937/fmet1803386J

(C) Faculty of Mechanical Engineering, Belgrade. All rights reserved uniform support around the bearing circumference to avoid stress peaks and large deformations of the bearing. For their stress-deformation (displacement) analyses mostly the finite element method (FEM) was used $[2,5,6,8,9]$.

The aim of the present research was to find an appropriate support solution of a large axial-radial bearing mounted on a slewing overhead travelling manipulator, in acceptable terms of manufacturing and price, which would reduce axial force peaks at the bearing circumference and increase the uniformity of their envelope. For this purpose a finite element (FE) model of the manipulator was established (Figure 1) upon which the impact of different bearing support solutions were examined. Beside axial reaction forces, also local relative deformations at the bearing circumference, support plate stress and support plate deformation states were investigated.

\section{METHODS}

In this research the FEM was taken as the main analysis tool to acquire large bearing loading and detailed stressstrain and deformation status of the supporting structure.

\subsection{Numerical model}

An FE model of an overhead travelling manipulator with a slewing superstructure (Figure 1) was established using Ansys. The model consists roughly of two parallel main girders (1), two end carriages (2), a horizontal supporting plate (3) welded between the two main girders and two transverse plates (4), a superstructure with hydraulic mechanism (5), reinforcement ribs (6), bearing rings (not visible) and 44 beams (7) connecting the bearing rings and the supporting plate at the places of the bearing bolt holes. This connection was modelled by beams to enable simple reaction forces read out. 


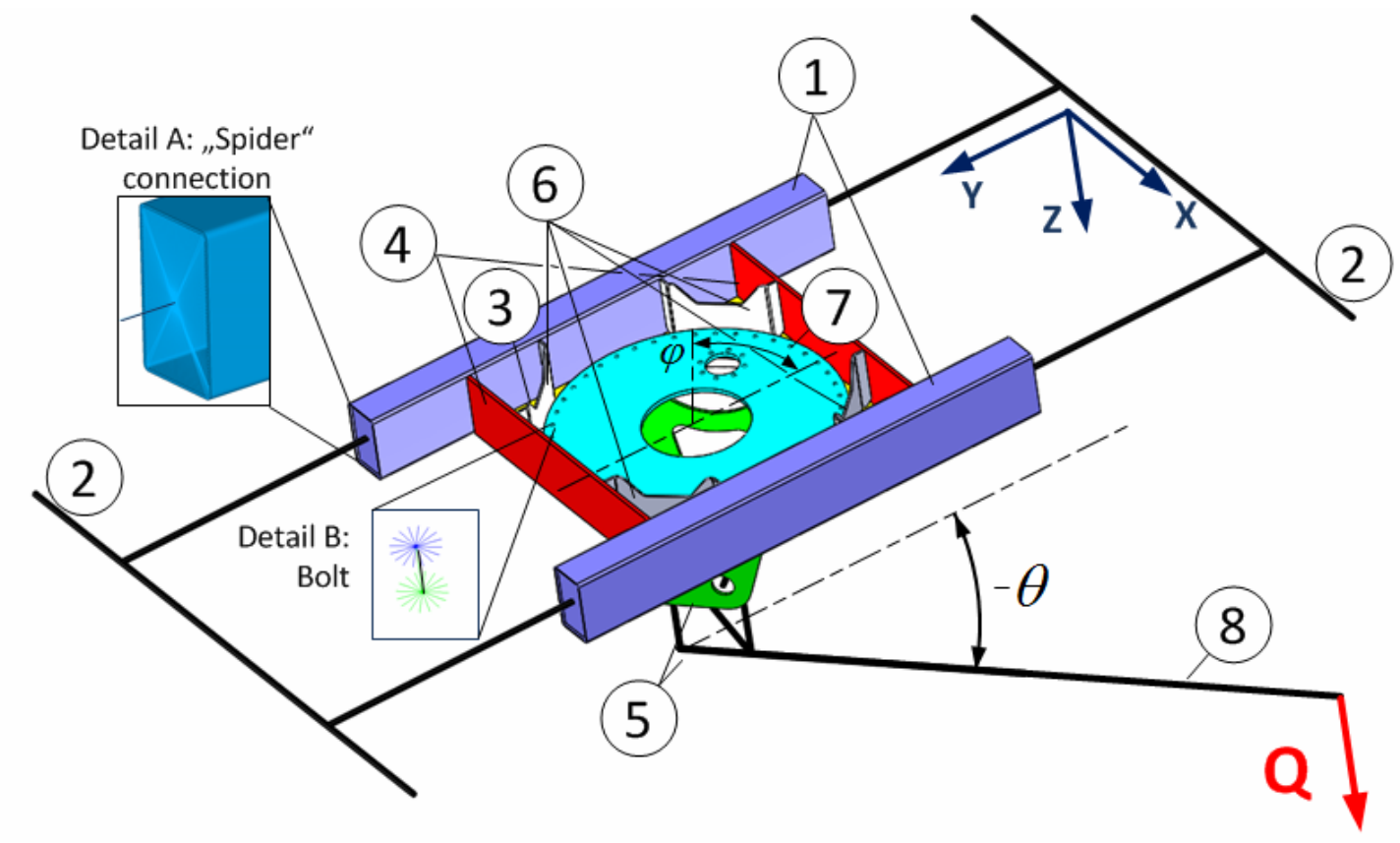

Figure 1. The FE model of an overhead travelling manipulator: (1) main girders, (2) end carriages, (3) horizontal supporting plate (also shown in figures 3 and 4), (4) transverse plates, (5) superstructure with hydraulic mechanism, (6) reinforcement ribs, (7) connecting beams and (8) lever arm. The bearing rings are present but not visible. denotes the slewing position of the lever arm and the position of the reaction force in the individual connecting beam at the bearing circumference.

Because the main intention of the model was to analyse the forces transmitted from the superstructure to the supporting plate there was no need for modelling of the bearing balls. All parts, except the simplified, were meshed with hexagonal solid FE (SOLID45). The end carriages, the outer parts of the main girders, beams and the lever arm of the manipulator mechanism (Figure 1, position 8) were simplified and meshed with beam FE (BEAM4).

The simplified and non-simplified parts of the main girders and the superstructure were connected via multiple beam FE, arranged into so called "spider web" (Figure 1, detail A), between the adjacent end nodes of the connecting parts. Such connections were also established between the circumferential nodes of the bolt holes in the supporting plate and bearing rings and the end nodes of the connecting beams (Figure 1, detail B).

Solid parts were connected by fillet and butt welds where this was applicable. Fillet welds were modelled as solids with defined bonded surface to surface contacts between the adjacent faces of the welds and the welded parts. Butt welds were considered as bonded surface contacts between the adjacent faces of the welded parts.

All the modelled components of the overhead travelling manipulator are made of steel S355. Because the load carrying structure operates in its elastic material range, elastic material model with Young's modulus E of $2.1 \cdot 105 \mathrm{MPa}$ and Poisson ratio of 0.3 was used.

\subsection{FE analyses}

For the optimization of the slewing superstructure's support the position of the reinforcement ribs between the main girders and the transverse plates was optimized via trial and error. For each proposed constructional solution static structural FEM analyses were performed for different slewing angles $\theta\left(0^{\circ}, \pm 41^{\circ}, \pm 49^{\circ}, \pm 90^{\circ}\right)$ of the hydraulic lever arm (see Figure 1). The load capacity of the manipulator is defined by means of maximal permissible moment $M_{\max }=90 \mathrm{kN} \mathrm{m}$ produced by the payload $\mathrm{Q}$ on the lever $\mathrm{L}$. In simulations the most unfavourable load case was used, which occurs when the lever is at its least extended position $(L=3 \mathrm{~m})$ with maximum permissible load applied $\left(Q_{\max }=30 \mathrm{kN}\right)$.

The FE model consisted of 926.811 FE. The computation time was approximately 35 minutes using a computer with 64 GB RAM and 10 processors (Intel ${ }^{\circledR}$ Core $^{\mathrm{TM}}$ i7-580K, $3.30 \mathrm{GHz}$ ).

\subsection{Local relative displacements at the bearing circumference}

Local relative displacements at the bearing circumference were calculated at each fastening bolt connecting the superstructure and the supporting plate as:

$$
\delta_{i}=\frac{U Z_{i+1}-U Z_{i-1}}{2}-U Z_{i}
$$

where $i$ runns over all fastening bolts and $U Z$ is the total displacement in the $\mathrm{Z}$ direction of the corresponding bolt.

\section{RESULTS AND DISCUSSION}

Axial reaction forces at the places of all the beams (fastening bolts), connecting the bearing, superstructure and the supporting plate, were obtained for the analysed positions $\theta$ of the hydraulic lever arm. These forces are presented in Figure 2 for the initial (a) and final (b) 
constructional solution in dependence of angle $\varphi$, which describes the position of the connecting beams (Figure 1).

In the initial construction solution the reinforcement ribs, the main girders and the transverse plates formed a regular eight-sided polygon (octagon), which is widely accepted as the best solution. In the final constructional solution the reinforcement ribs were moved further apart for 77 millimetres.

The coloured solid curves (Figure 2) were acquired from numerical analyses; the dashed coloured curves were derived from the appropriate solid curves considering symmetry. For example, the curve for $\theta=$ $221^{\circ}$ was created by taking the curve for $\theta=41^{\circ}$ and increasing the values of $\varphi$ by $180^{\circ}$. Black curves present the maximal positive and negative reaction forces for all the analysed positions $\theta$ (force envelopes). The doted black line in Figure 2 (a) is the force envelope of the initial solution, the solid black line in Figure 2 (b) is the force envelope of the final solution. To enable comparison, these force envelopes are presented together in Figure 2, c. They have a twice symmetrical shape shifted onto the compressive side due to the external axial loading Q. Four maximums appear in the tensile, respectively minimums in the compressive force envelopes at approximate $\varphi$ angles:

$$
\pi / 4+k \cdot \pi / 2 ; k \in \mathbb{Z}
$$

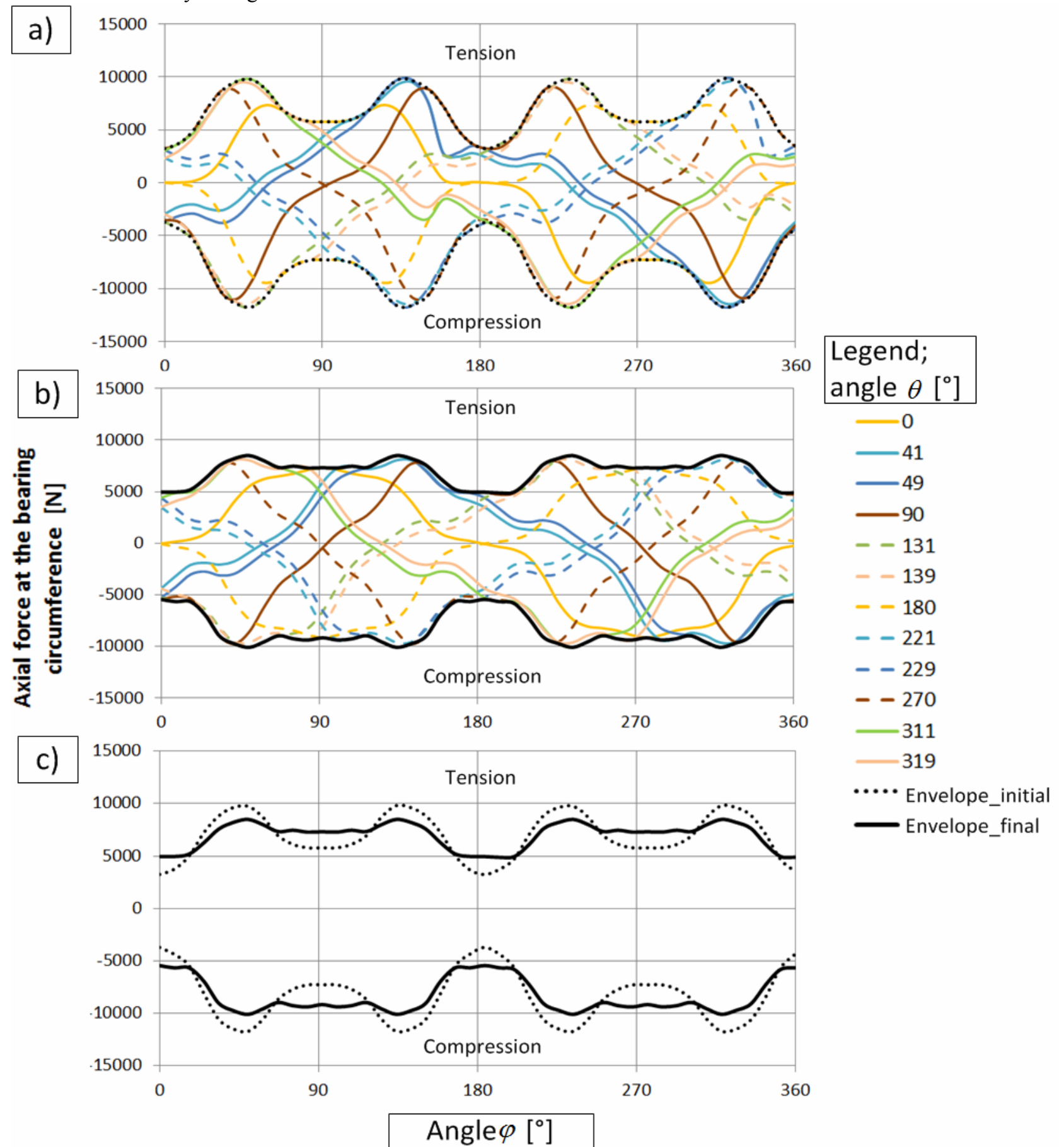

Figure 2. Axial reaction forces at the bearing circumference in dependence of the lever arm position $\theta$ for the initial (a) and final (b) support solution. The solid curves present numerical results. The dashed curves were derived from the appropriate solid curves. Black curves present the maximal tensile and compressive reaction forces for all the analysed positions (force envelopes). In (c) initial and final force envelopes are presented together. 
In the initial solution the reinforcement ribs were closer to the bearing and the support at these areas acted too stiff. Consequently, the maximal positive and negative reaction forces were increased and shifted from the expected locations at both tips of the bearing (the points at the bearing circumference most distant from the tilting axe) toward the ribs. Furthermore, reaction forces were not distributed equally.

When the lever arm is at slewing positions $\theta=0^{\circ}$ and $\theta=90^{\circ}$ torque around the global $x$, respectively $y$, axis is produced. The manipulator's overhead travelling bridge has a higher load bearing capacity for the tilting moment around the $x$ then around the $y$ axis. Because of that the total displacements in Figure 5 differ much for slewing positions $\theta=0^{\circ}$ and $\theta=90^{\circ}$.
For better presentation of the support plate state its local relative deformations at the bearing circumference in the $\mathrm{Z}$ direction (Figure 1) are presented in Figure 3 for the initial (a) and final (b) constructional solution, in the same manner as reaction forces are presented in Figure 2.

In Figure 3, c, local relative displacement envelopes of the initial and final solution are presented for better comparison. As expected, the final solution yields higher $(42.5 \%)$ maximal relative displacements as the initial solution, due to the more flexible support. Form this it follows: the more flexible the support, the lower are the reaction forces and the greater are the deformations. From comparison of charts in Figure 2 and 3 it can be seen, that at the angles $\varphi$, where reaction forces are high, the relative displacements are low, and vice versa.
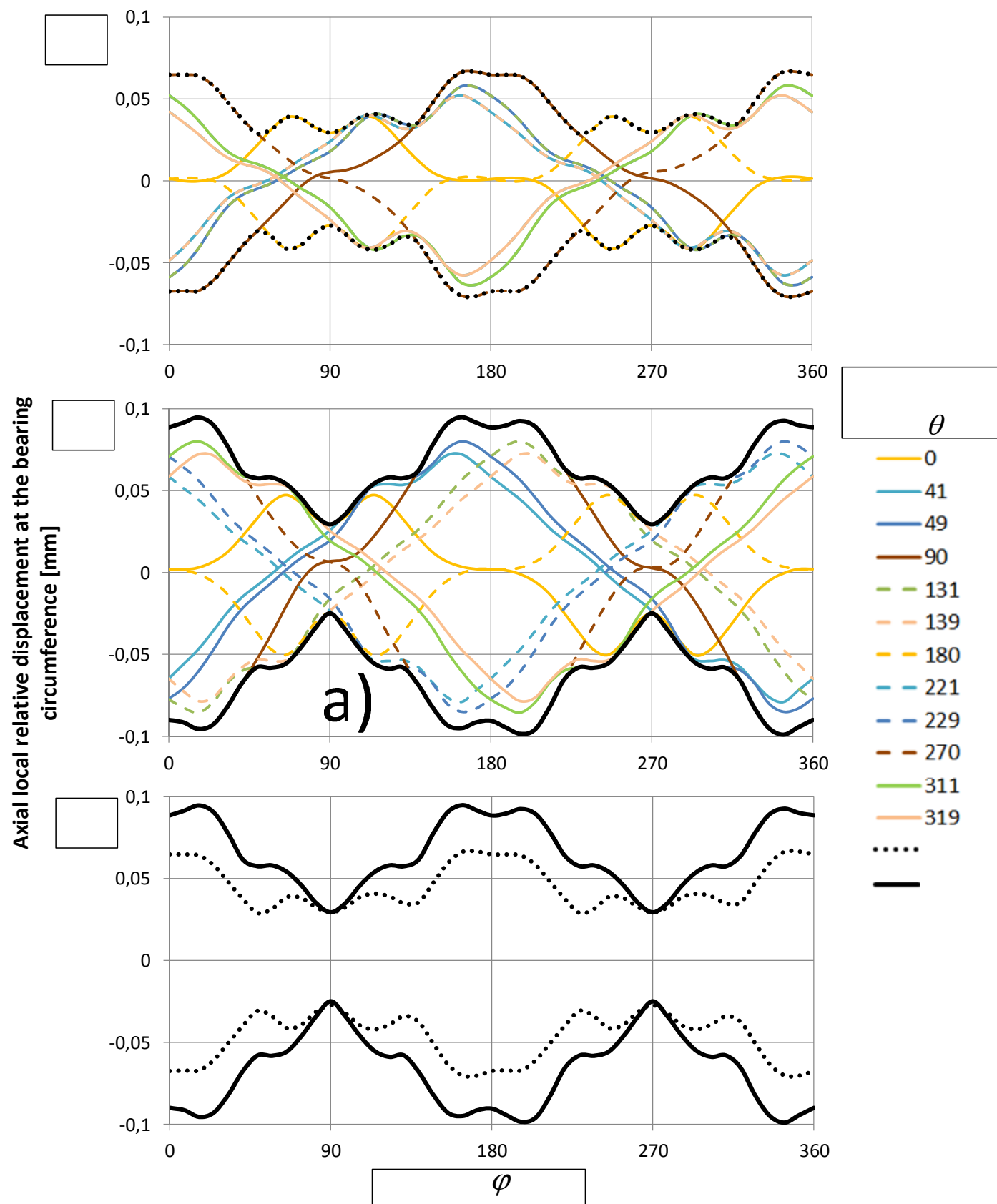

Figure 3. Axial local relative displacements at the bearing circumference in dependence of the lever arm position $\theta$ for the initial (a) and final (b) support solution. The solid curves present numerical results. The dashed curves were derived from the appropriate solid curves. Black curves present the maximal relative displacements in the $Z$ direction for all the analysed positions (local relative displacement envelopes). In (c) initial and final local relative displacement envelopes are presented together. 
However, high relative displacements at the bearing circumference are normally not desired, because they can hinder the relative movement of the bearing. But in the investigated case, these deformations were not critical; therefore it was reasonable to increase these deformations, while decreasing the reaction forces. Moreover, the final support construction is less stiff than the initial, which is not in agreement with suggestions of stiff roller-bearing support [1, 4-8]. But in the investigated case only such solution enabled more uniform reaction force distribution, while simultaneusly satisfying criterion of allowable stress.

In Figure 4 different Von Mises stress distributions can be observed for the $\theta=0^{\circ}$ and $\theta=90^{\circ}$ lever arm slewing positions. The difference occurs due to the difference in the bearing support structure and its loadings; the support's main frame consists of two main girders and two transverse plates (Figure 1). Furthermore the main girders are subjected to global loading, and therefore have additional related deformations.

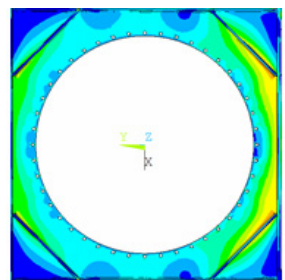

$\theta=0^{\circ}$
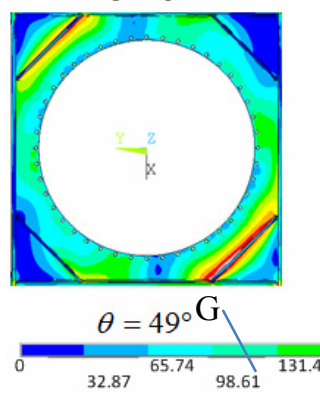

Figure 4. Von Mises stress distribution in the support plate for the final solution for different angles $\theta$ of the lever arm. Grey colour (G) presents areas with von Mises stress above the maximal stress of the selected scale.

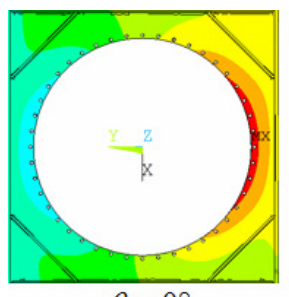

$\theta=0^{\circ}$

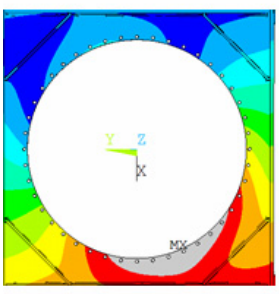

$\theta=49^{\circ}$

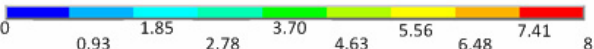

Figure 5. Total deformation distribution in the support plate for the final solution for different slewing angles $\theta$ of the lever arm. Grey colour (G) presents areas with total deformations above the selected deformation scale.
In the final support solution maximal tensile and compressive forces at the bolt places were reduced for $13 \%$. The reaction forces were also more uniformly distributed than in the initial support solution; in the initial solution the ratio between the maximum and minimum tensile forces of the envelope $R_{\text {tens }}$ was 3.03, while for the compressive forces the ratio $R_{\text {comp }}$ was 3.16. In the final solution these ratios were reduced to 1.74 and 1.85 , which is a $74 \%$ and $70 \%$ reduction of these ratios, respectively.

The von Mises stress distribution in the final solution of the bearing support for four different positions of the lever arm is presented in Figure 4. In Figure 5 total deformation (including the deformation of the whole crane) distribution in the final support solution is presented for the same angles of the lever arm. Position of the lever arm at $\theta=90^{\circ}$ is the most critical regarding the von Mises stress and also regarding the total displacements. Whereas this was expected regarding the displacements, on the other hand the difference of stresses in the supporting plate is more surprising and commented in discussion. Position of the lever arm at $\theta=0^{\circ}$ is the less critical regarding the observed criteria, while the other two positions of the lever arm $\left(\theta=41^{\circ}, 49^{\circ}\right)$ give similar results somewhere between the less and most critical results.

\section{CONCLUSION}

Support of the slewing superstructure turned out to be an important influence on the large radial-axial bearing load distribution which was considered in this paper trough the reaction forces at the places of the fastening bolts connecting the bearing rings, the superstructure and the supporting plate. By trial and error optimization of the reinforcement rib positions maximal tensile and compressive reaction forces at the bolt places were reduced by $13 \%$. The reaction forces were also more uniformly distributed in the final support solution. The ratios that evaluated this uniformity were reduced by $74 \%$ for tensile forces and $70 \%$ for compressive forces. For such result the reinforcement ribs were moved further apart from each other, which resulted in unequal distances between the bearing, as an inscribed circle, and the stiff supporting elements (main girders, transverse plates and reinforcement ribs) positioned in the form of an irregular octagon surrounding the bearing. This way, a more appropriate stiffness distribution of the bearing support was achieved, resulting in more favourable bearing loading. As a consequence of lower reaction forces, the local relative displacement at the bearing circumference increased by $42.5 \%$. However, in the investigated case these deformations were still below the allowable deformations. The proposed solution is an example of a more favourable flexible bearing support in contrast to the general stiff bearing support recommendations [1, 4-8].

It has been found that in the case when the classic solution with appropriately stiff bearing support is not an option the uniformity of the bearing loading can be achieved by optimization of the reinforcement ribs location. The proposed solution is optimal considering 
price and manufacturing limitations. The uneven design of the supports main frame and the design of the superstructure's circular supporting plate are also taken into account. If these limitations were ignored, other more complex solutions may be favourable.

\section{REFERENCES}

[1] Zupan, S., Prebil, I. Carrying angle and carrying capacity of a large single row ball bearing as a function of geometry parameters of the rolling contact and the supporting structure stiffness, Mech Mach Theory, 36, 10, pp. 1087-1103, 2001.

[2] Kania, L.: Modelling of rollers in calculation of slewing bearing with the use of finite elements, Mech Mach Theory, 41, 11, pp. 1359-1376, 2006.

[3] Lazovic, T., Ristivojevic, M., Mitrovic, R. Mathematical Model of Load Distribution in Rolling Bearing, FME Transactions, 36, pp. 198196, 2008.

[4] Jovanovic, V. D., Janosevic, D. B., Marinkovic, D. Z.: Determination of the load acting on the axial bearing of a slewing platform drive in hydraulic excavators, Acta Polytech Hung, 12, 1, pp. 5-22, 2015.

[5] Smolnicki, T., Derlukiewicz, D., Stanco, M.: Evaluation of load distribution in the superstructure rotation joint of single-bucket caterpillar excavators, Automat Constr; 17, 3, pp. 218-223, 2008.

[6] Potočnik, R., Flašker, J., Göncz, P., Glodež, S.: Numerical analysis of 3D surface crack propagation in a large slewing bearing, ECF18, Dresden, Germany, 2012.

[7] Smolnicki, T., Rusinski, E.: Superelement-based modeling of load distribution in large-size slewing bearings, J Mech Design, 129, 4, pp. 459-463, 2007.

[8] Smolnicki, T., Stanco, M., Pietrusiak, D.: Distribution of loads in the large size bearing problems of identification, Teh Vjesn; 20, 5, pp. 831-836, 2013.

[9] Rusiński, E., Czmochowski, J., Pietrusiak, D. Selected Problems in Designing and Constructing Surface Mining Machinery, FME Transactions, 40, pp. 153-164, 2012.

\section{ОПТИМИЗАЦИЈА НОСЕЪЕ КОНСТРУКЦИЈЕ АКСИЈАЛНО-РАДИЈАЛНОГ ЛЕЖАЈА ВЕЛИКИХ ДИМЕНЗИЈА КОД НАДЗЕМНИХ МАНИПУЛАТОРА}

\section{Б. Јерман, Ј. Хладник, Ф. Ресман, К. Ландшуцер}

Аксијално-радијални лежајеви великих димензија се примењују за спајање механизама за закретање угла код дизалица и тешких машина. Уколико је носећа конструкција неодговарајућа оптерећење може да спречава функционисање повратног лежаја, па чак да доведе и до његовог лома. У овом раду оптимизиран је носач радијалног лежаја великих димензија који је монтиран на надземном манипулатору у циљу минимизације дејства сила реакције између прстена и носача лежаја и повећања хомогеног дејства сила реакције. ФЕ модел кретања надземног манипулатора је установљен и конфигурација ојачања носеће конструкције је успешно оптимизирана. Код коначног решења максималне затезне и притисне силе реакције су смањене за $13 \%$ у поређењу са почетним решењем. Такође је хомогеност затезне и притисне максималне силе реакције побољшана за $74 \%$ односно $70 \%$. 